\title{
İki Kere Farklı: Özel Yetenekli ve Otizmli Bireyler Hakkında Ne Biliyoruz? Bir Sistematik Alanyazın Taraması
}

\section{Twice Exceptional: What Do We Know About Gifted Individuals with Autism? A Systematic Literature Review}

\author{
Furkan ATMACA ${ }^{1}$, Sema TAN ${ }^{2}$
}

\begin{abstract}
${ }^{1}$ Sorumlu Yazar, Arş. Gör., Özel Eğitim Bölümü, Eğitim Fakültesi, Hacettepe Üniversitesi, Türkiye, furkan.atmaca@hacettepe.edu.tr, (https://orcid.org/0000-0003-0937-1839)

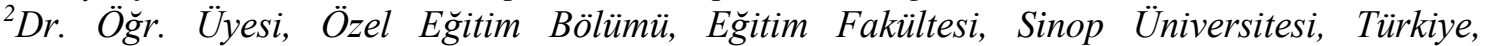
sematan@sinop.edu.tr, (https://orcid.org/0000-0002-9816-8930)
\end{abstract}

Geliș Tarihi: 02.02.2021

Kabul Tarihi: 27.12.2021

\section{ÖZ}

$\mathrm{Bu}$ araştırmada hem özel yetenekli hem de otizm spektrum bozukluğu olan iki kere farklı bireylere yönelik ulusal ve uluslararası alanyazında yer alan çalışmaların sistematik olarak incelenmesi amaçlanmıştır. Bu kapsamda veri tabanları ve anahtar kelimeler belirlenerek taramalar yapılmıştır. Taramalarda ulaşılan çalışmalardan 17 makale dâhil etme ve dışlama kriterleri neticesinde bu araştırmada incelenmek üzere belirlenmiştir. Belirlenen çalışmalar otizmli iki kere farklı bireylerin özellikleri, tanılama süreci, müdahaleler ve aileleri temaları altında incelenmiştir. Araştırmadan elde edilen bulgular otizmli iki kere farklı bireylerin birçok akademik ve bilişsel beceri alanında ortalama üzeri performans sergilemelerine karşın sosyal becerilerde ve iletişim becerilerinde güçlükler yaşadıklarını göstermektedir. Bu bireylerin tanılama süreçlerinde sadece otizm ya da sadece özel yetenek değerlendirmelerinin etkili sonuçlar vermeyebildiği görülmektedir. Bu nedenle çoklu değerlendirme yaklaşımları gerekli görülmektedir. Etkili müdahale yaklaşımları için bu bireylerin güçlü yönlerine odaklanan ve zayıf yönlerini de göz önünde bulunduran yaklaşımlar gereklidir. Elde edilen bulgular alanyazın ışı̆̆ında tartışılmıştır.

Anahtar Kelimeler: İki kere farklı, otizm, özel yetenek, üstün zeka, sistematik alanyazın taraması.

\begin{abstract}
The research aims to systematically review the studies conducted with twice exceptional individuals who are gifted and have autism spectrum disorder. In this context, several databases were searched using specific keywords. 17 articles were determined to be examined after the application of the inclusion and exclusion criteria. The identified studies were examined under the themes of characteristics, diagnosis process, interventions, and families of twice exceptional individuals with autism. The findings showed that twice exceptional individuals with autism experienced difficulties in social and communication skills, although they performed above average in many academic and cognitive skill areas. The findings further indicated that only autism or only gifted evaluations may not be effective in the identification process of these individuals. Therefore, multiple assessment approaches and/or measures are required. For effective interventions, approaches that focus on the strengths of these individuals and consider their weaknesses are necessary. The findings were discussed in light of the literature.
\end{abstract}

Keywords: Twice exceptional, autism, gifted, talented, systematic literature review. 


\section{GíRiş}

Otizm spektrum bozukluğu (OSB), sosyal etkileşim ve iletişimdeki yetersizliklerle, sınırlı ve tekrarlayıcı davranış örüntüleri ile karakterize olan nörogelişimsel bir bozukluk olarak tanımlanmaktadır (American Psychiatric Association [APA], 2013). Öte yandan özel yetenekli (ÖY) birey, akranlarına oranla zekâ, yaratıcılık, sanat, liderlik kapasitesi ya da özel akademik alanlarda anlamlı derecede yüksek performans sergileyen bireyler olarak tanımlanabilir (Millî Eğitim Bakanlığı [MEB], 2013). OSB gibi nörogelişimsel bozukluklardan etkilenmiş bireyler özel gereksinimli olduğu gibi ÖY bireyler de özel gereksinimli olarak kabul edilmektedir (Baykoç Dönmez, 2017). Özel gereksinimli bireylerin eğitim-öğretim süreçlerinde ve sosyal hayatta başarılı olabilmelerinde erken dönemde tanılama ve etkili özel eğitim hizmetleri önemli bir yer tutmaktadır. Bunun için öğrencinin ve özel gereksinimin özelliklerinin iyi bilinmesi gerekmektedir. Ancak bu kolay bir süreç değildir. Bazı bireyler tek bir özel gereksinim grubunda yer almamakta, birden fazla tanı alabilmektedir. Örneğin bazı bireyler hem ÖY hem de farklı bir özel gereksinim tanısını birlikte alabilmektedir. OSB, öğrenme güçlüğü ya da dikkat eksikliği hiperaktivite bozukluğu gibi bir tanı ile birlikte ÖY tanısı alan bireyler iki kere farklı birey olarak tanımlamaktadır (Baldwin, Baum, Pereles ve Hughes, 2015). Reis, Baum ve Burke (2014) ise iki kere farklı bireyi şu şekilde tanımlamaktadır:

\footnotetext{
... matematik, bilim, teknoloji, sosyal sanatlar, görsel, mekânsal veya sahne sanatları ya da insan üretkenliğinin diğer alanları gibi bir veya daha fazla alanda yüksek başarı ya da yaratıcı üretkenlik potansiyeli ile birlikte resmi makamlarca belirlenen kriterlere göre tanılanmış bir ya da daha fazla engel/yetersizlik gösteren bireyler... (s. 222).
}

İki kere farklılı̆̆ın üzerinde uzlaşılmış bir tanı profili bulunmamaktadır (Amend, 2018). Bu nedenle, iki kere farklılık, hem tanılama süreçlerini hem de etkili özel eğitim hizmetlerinin sunulmasını zorlaştıran bir unsur olarak karşımıza çıkmaktadır. Ayrıca iki kere farklı bireyler, ne sahip oldukları yetersizlik ne de ÖY tanımlarını tam olarak karşılamadıkları için zorluklarla dolu bir eğitim süreci geçirmektedir (Reis ve diğerleri, 2014). Öte yandan iki kere farklı bireylerin farklılaşan ihtiyaçları bazı alan uzmanlarının yetersizliği olan bireylerin gerçekten üstün zekalı ya da özel yetenekli olabileceğini kabul etmemesiyle sonuçlanabilmektedir (FoleyNicpon, Allmon, Sieck ve Stinson, 2011; Vaughn, 1989). Bununla birlikte son y1llarda artan kanıta dayalı bilgiler neticesinde öğrenme, dikkat, sosyal beceriler gibi alanlarda güçlükler yaşayan bireylerin aynı zamanda ÖY olabileceği düşüncesi eğitimciler, okullar ve aileler tarafından kabul edilmeye başlanmıştır (Baum ve Owen, 2004; Foley-Nicpon ve diğerleri, 2011). Ancak bazı alan uzmanları hala ÖY ve yetersizlik kavramlarının birlikte olmasının bir uyumsuzluk olduğunu düşünmektedir (Baum, Rizza ve Renzulli, 2006). Örneğin bazı eğitimcilerin iki kere farklı bireylerin üst düzey programlara alınmasına karşı olduklarını, programlara alınsalar bile bu bireylerin ihtiyaçları doğrultusunda programın şekillendirilmediğini gösteren araştırmalar bulunmaktadır (Schultz, 2011). Bu durum, iki kere farklı bireylerin ihtiyaç duydukları sosyal-duygusal desteği de alamamalarına sebep olmaktadır. Galbraith (2018), iki kere farklı bireylerin sosyal-duygusal açıdan desteklenmesi gerektiğini ve bu destekle başarıya ulaşabileceklerini ifade etmektedir. Benzer şekilde, iki kere farklı öğrencilerin yakın arkadaşlık ilişkilerini inceleyen Conejeros-Solar ve diğerlerinin (2021) araştırması, sosyal desteğin bu bireyler için ne kadar önemli olduğunu göstermektedir. Ancak uygun desteğin sağlanması bir yana, genellikle yeteneklerin yetersizlikleri ya da yetersizliklerin yetenekleri maskelemesi sonucunda iki kere farklı bireylerin tespit edilemediği ifade edilmektedir (Reis ve diğerleri, 2014).

OSB olan iki kere farklı bir bireyin uygun özel eğitim hizmetlerinden faydalanabilmesi için hem OSB hem de ÖY durumlarının detaylı bir şekilde incelenmesi gerekmektedir. Zekâ, davranış ve sosyal becerileri içeren uygun bir değerlendirme ile iki kere farklı bireyler ve OSB olan bireyler arasındaki farklılıklar açık bir şekilde görülebilmektedir (Assouline, Foley-Nicpon ve Doobay, 2009). Ancak özellikle tanılama süreçlerinde çalışan alan uzmanlarının bu iki durumu da detaylı bir şekilde tanılayacak alt yapıya sahip olmadıkları görülmektedir (Foley- 
Nicpon ve diğerleri, 2011). Bu nedenle bu öğrencilerle çalışacak öğretmen, psikolog, psikiyatrist gibi alan uzmanlarının OSB'li iki kere farklı bireyler hakkında da eğitimler alması gerekmektedir (Henderson, 2001). Öte yandan iki kere farklı bireylerin nasıl tanımlanması ve nasıl tanılanması gerektiğine ilişkin bir fikir birliği olmadığı görülmektedir (McCoach, Kehle, Bray ve Siegle, 2001; Ruban ve Reis, 2005).

Tanılamada yaşanılan güçlüklerin bir sonucu da uygun özel eğitim hizmetlerinin sağlanması noktasında karşımıza çıkmaktadır. İki kere farklı bireyler sahip oldukları farklılıklar nedeniyle doğru tanı alamamakta ve bu durum uygun eğitsel hizmetlerin sağlanmasına engel teşkil etmektedir. İki kere farklı bireylere uygun özel eğitim hizmetlerinin sağlanabilmesi ve doğru tanılama yapılabilmesi için yeterli düzeyde kanıta dayalı ve kuramsal bilginin bir arada olması gereklidir (Rubenstein, Pierson, Wilczynski ve Connoly, 2013). Ancak alanyazında OSB'li iki kere farklı bireyler ile yürütülen deneysel çalışmaların kısıtlı sayıda olduğu görülmektedir (Assouline ve diğerleri, 2009). Bu nedenle iki kere farklı bireylerin gözden kaçması ya da etkisiz programlara tabi tutulması söz konusu olabilir (Huber, 2007). Bazı araştırmacılar, iki kere farklı bireyler için en az kısıtlayıcı ortamın hem güçlük yaşadıkları alanlarda hem de ÖY oldukları alanlarda destek eğitim hizmetleri almalarıyla sağlanacağını ifade etmektedir (Weinfeld, Barnes-Robinson, Jeweler ve Shevitz, 2002). Ancak genellikle akranları düzeyinde başarı sergiledikleri sürece bu bireylerin okullarda başarılı olduklarına ve harici bir destek eğitim hizmetine ihtiyaç duymadıklarına yönelik bir inanış hüküm sürmektedir (Foley-Nicpon ve diğerleri, 2011).

OSB olan ÖY öğrencilerin doğru bir şekilde tanılanması ve uygun müdahalelerin planlanması için var olan bilgilerin bir bütün olarak ele alınması gerekmektedir. Fakat alanyazında OSB ile ilgili çok sayıda araştırma olmasına karşın hem OSB hem de ÖY olan bireylerle ilgili çok sınırlı sayıda bilgiye ulaşılabilmektedir. Ayrıca iki kere farklı bireylerle yapılan çalışmaların derlendiği farklı araştırmalar olduğu görülmektedir (Beckmann ve Minnaert, 2018; Yılmaz-Yenioğlu ve Melekoğlu, 2020). Ancak OSB özelinde iki kere farklı bireylerle ilgili çalışmaların derlendiği araştırmaların da kısıtlı sayıda olduğu görülmektedir (Foley-Nicpon ve diğerleri, 2011). Pfeiffer ve Foley-Nicpon (2018), iki kere farklılığa ilişkin var olan bilgilerin çoğunlukla klinik vaka raporlarına dayandığını ve bu alanda yürütülmüş geniş kapsamlı araştırmaların kısıtlı olduğunu ifade etmektedir. Tüm bu bilgiler bir arada değerlendirildiğinde OSB'li iki kere farklı bireyler ile yapılmış çalışmaların bir araya getirilerek var olan bilgilerin derlenmesinin bir ihtiyaç olduğu düşünülmektedir. Bu yolla alanyazında var olan durum hakkında bir yargıya varılabilecek, gelecekte yapılacak olan araştırmalar için önerilerde bulunulabilecektir. Bu doğrultuda bu araştırmanın amacı, ulusal ve uluslararası alanyazında OSB'li iki kere farklı bireylere yönelik yapılan çalışmaları sistematik bir şekilde incelemektir.

\section{YÖNTEM}

$\mathrm{Bu}$ çalışma, elektronik ortamda elde edilen veriler ile yürütülen bir sistematik alanyazın taramasıdır. Bu kapsamda, Aralık 2020 içerisinde ERIC ve ProQuest veri tabanları taranmıştır. Taramalarda "autism", "twice exceptional", "gifted" ve "talented" anahtar sözcükleri farklı kombinasyonlarla kullanılmıştır. Türkçe araştırmaların taranmasında ULAKBİM ve DergiPark sistemleri kullanılmıştır. Taramalarda "otizm”, "iki kere farklı", "özel yetenek", "üstün yetenek", "üstün zeka" anahtar sözcükleri kullanılmıştır.

Araştırmanın dahil etme kriterleri, a) hakemli dergilerde yayınlanmış makale olması, b) tam metninin Türkçe veya İngilizce yazılmış olması, c) tam metnine erişilebilir olması, d) eğitim, özel eğitim, özel yetenekliler eğitimi ya da psikoloji alanlarında yayımlanmış olması şeklinde belirlenmiştir. Dışlama kriterleri, a) ampirik veri içermiyor olması, b) özel yetenekli ve OSB olan bireyler ya da bu bireylerin aileleri dışında bir örneklemle çalışılmış olması, b) tanı kriterlerinin 
belirsiz olması, c) ÖY tanısı için en az 90. Persentil (120 IQ veya üzeri) kriterinin belirlenmemiş olması, d) örneklemin OSB ve özel yetenek dışında farklı eş tanılara sahip olması şeklinde belirlenmiştir.

Taramalarda ERIC veri tabanında 177 ve ProQuest veri tabanında 296 sonuca ulaşılmıştır. ULAKBIM ve DergiPark sistemlerinden herhangi bir çalışmaya ulaşılamamıştır. Taramalarda ulaşılan çalışmalar ilk aşamada dahil etme kriterleri ile sınırlandırılıp tekrar eden çalışmalar elendikten sonra çalışma sayısı 178'e inmiştir. Ardından bu çalışmaların başlık, özet, yöntem ve kaynakça bölümleri dahil etme, dişlama kriterleri doğrultusunda tekrar gözden geçirilmiştir. $\mathrm{Bu}$ doğrultuda kriterleri sağlayan 16 çalışma belirlenmiştir. Ulaşılabilen araştırmalar kısıtlı sayıda olduğu için örneklemi sadece OSB'li iki kere farklı bireyler ya da bu bireylerin ailelerinden oluşmayan ancak bu bireyleri de içeren çalışmalar da bu araştırmaya dahil edilmiştir. Farklı araştırmaların kaynakçaları incelenerek dört çalışmaya daha ulaşı1mış, kriterler doğrultusunda bu çalışmalardan biri araştırmaya dahil edilmiştir. Sonuç olarak, toplam 17 çalışma bu araştırmada incelenmek üzere belirlenmiştir. Makaleleri belirlenen veri tabanları ve anahtar kelimelerle tarama süreci birinci yazar tarafından yürütülmüştür. Tarama sürecinde ulaşılan makaleler birinci ve ikinci yazar tarafından eş zamanlı olarak dahil etme ve hariç tuma kritleri 1şı̆̆ında değerlendirilmiştir.

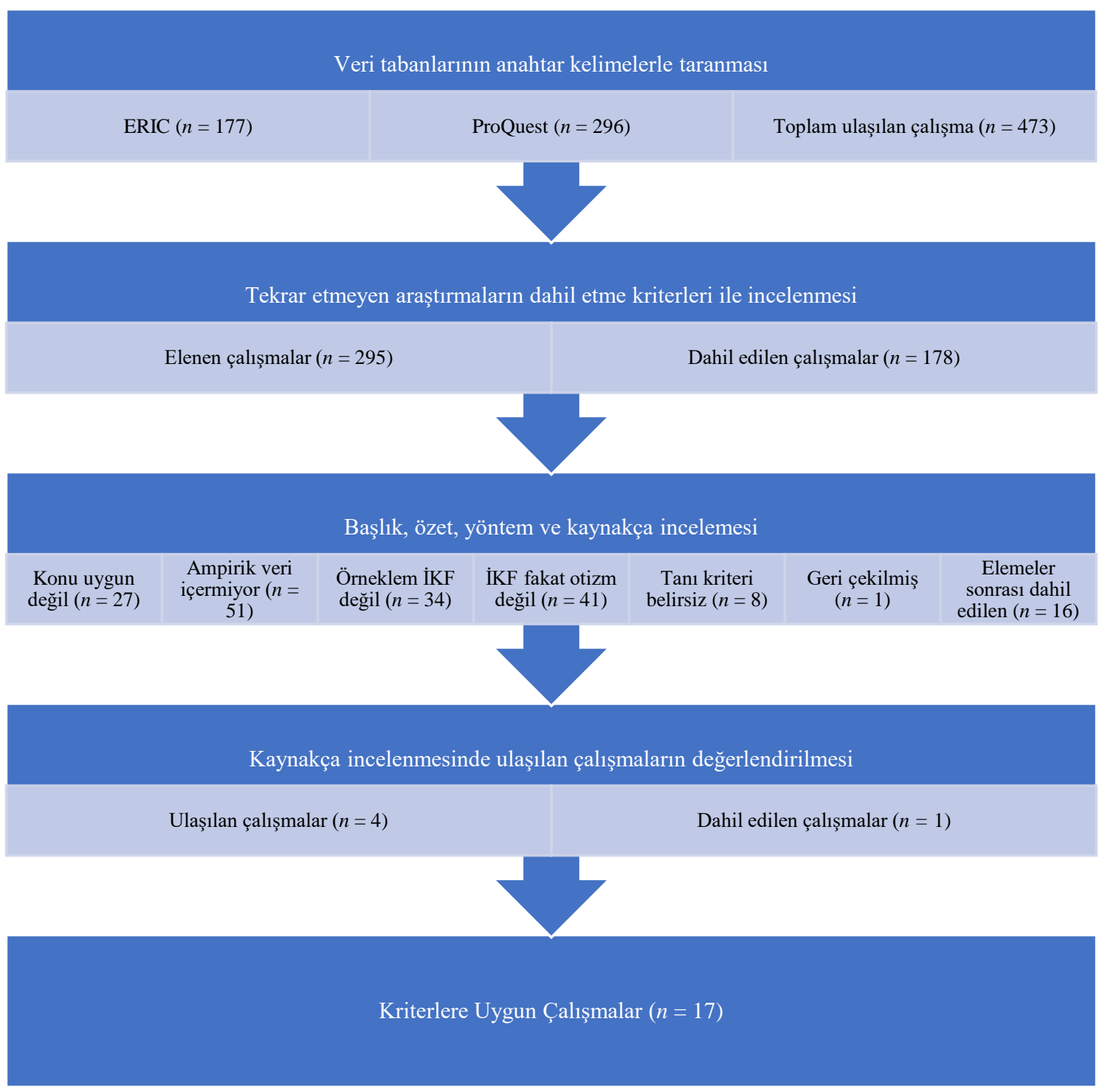

Şekil 1. Araştırmaları Belirleme Süreci 
Temalar araştırmacıların tarama sonucunda elde edilen makaleleri incelemesi ve bu makalelerin bulgularındaki örüntüleri tespit etmesi ile belirlenmiştir. Buna göre araştırmacılar OSB/ÖY olan bireylerin özellikleri, OSB/ÖY olan bireylerin tanılama süreci, OSB/ÖY bireylere yönelik müdahaleler ve $\mathrm{OSB} / \mathrm{O} Y$ bireylerin ailelerinin yaşadıkları güçlükler temaları üzerinde görüş birliğine varmışlardır. Görüş ayrılığı olduğu durumlarda araştırmacılar ortak bir görüşe varıncaya kadar konu üzerinde çalışmışlardır. $\mathrm{Bu}$ düzlemde temalar, incelen araştırmaların amaçları ve temel bulguları 1şığında, araştırmacıların görüş birliğiyle belirlenmiştir.

Belirlenen 17 çalışma amaç, örneklem, yöntem, veri toplama araçları ve temel bulgular açısından derlenmiştir. Aşağıdaki tabloda elde edilen bulgular yer almaktadır. 
Tablo 1. İncelenen Araştırmalar

\begin{tabular}{|c|c|c|c|c|c|}
\hline Kaynak & Amaç & Örneklem & Yöntem & Veri Toplama Araçları & Temel Bulgular \\
\hline $\begin{array}{l}\text { Assouline ve } \\
\text { diğerleri (2009) }\end{array}$ & $\begin{array}{l}\text { Sosyal güçlükler ve ÖY } \\
\text { arasındaki ilişkinin belirlenmesi }\end{array}$ & $\begin{array}{l}1 \text { OSB/ÖY öğrenci } \\
1 \text { ÖY öğrenci }\end{array}$ & Vaka Analizi & $\begin{array}{l}\text { Autism Diagnostic Observation } \\
\text { Schedule (ADOS) } \\
\text { Wechsler Intelligence Scale for } \\
\text { Children (WISC) - IV } \\
\text { Woodcock-Johnson } \\
\text { Achievement Battery (WJ) - III } \\
\text { Social Skills Rating System } \\
\text { (SSRS) } \\
\text { Behavioral Assessment System } \\
\text { for Children (BASC) - II } \\
\text { Autism Diagnostic Interview } \\
\text { (ADI-R) } \\
\text { Viveland Adaptive Behavior } \\
\text { Scales (Viveland) - II } \\
\text { NEPSY-II: A Developmental } \\
\text { Neuropsychological } \\
\text { Assessment, Second Ed. }\end{array}$ & $\begin{array}{l}\text { Bilişsel performans } \\
\text { değerlendirmesine ek olarak OSB } \\
\text { tanısı için ek ölçütler ve } \\
\text { değerlendirmeler gerekmektedir. } \\
\text { Öğrenciler bilişsel becerilerde benzer } \\
\text { performans sergilemelerine karşın } \\
\text { sosyal uyum ve yürütücü işlevlerde } \\
\text { farklılaşmıştır. }\end{array}$ \\
\hline $\begin{array}{l}\text { Assouline, Foley- } \\
\text { Nicpon ve } \\
\text { Dockery (2012) }\end{array}$ & $\begin{array}{l}\text { OSB/ÖY öğrencilerin başarı } \\
\text { düzeylerinin } \\
\text { öngörülebilirliğinin } \\
\text { belirlenmesi }\end{array}$ & 59 OSB/ÖY öğrenci & Nicel & $\begin{array}{l}\text { WISC-IV } \\
\text { WJ-III } \\
\text { Beery-Buktanica Test of Visual } \\
\text { Motor Integration (WMI) }\end{array}$ & $\begin{array}{l}\text { WISC-IV çalışma belleği ve } \\
\text { işlemleme hızı indeksleri ile } \\
\text { matematik, okuma ve yazma } \\
\text { becerileri arasında anlamlı ilişkiler } \\
\text { belirlenmiştir. Fakat hızlandırma ve } \\
\text { OSB tanısı ile akademik beceriler } \\
\text { arasında ilişki belirlenememiştir. }\end{array}$ \\
\hline
\end{tabular}




\begin{tabular}{|c|c|c|c|c|c|}
\hline $\begin{array}{l}\text { Baum, Schader ve } \\
\text { Hébert (2014) }\end{array}$ & $\begin{array}{l}\text { İKF öğrencilerin güçlü } \\
\text { yönlerine dayalı eğitim sistemi } \\
\text { olan bir ortaokuldan mezun } \\
\text { olan öğrencilerin } \\
\text { deneyimlerinin belirlenmesi }\end{array}$ & $\begin{array}{l}3 \text { Asperger/ÖY olan } \\
\text { toplam } 16 \text { İKF } \\
\text { öğrenci }\end{array}$ & Vaka Analizi & $\begin{array}{l}\text { Öğrenci ve öğretmen } \\
\text { görüşmeleri } \\
\text { Aile odak grup } \\
\text { Eğitim kayıtları } \\
\text { Psikolojik raporlar }\end{array}$ & $\begin{array}{l}\text { Öğrencilerin bilişsel, } \\
\text { duygusal/davranışsal ve sosyal } \\
\text { alanlarda gelişim gösterdiği } \\
\text { belirlenmiştir. Bu gelişim altında } \\
\text { yatan beş faktör psikolojik güvenlik, } \\
\text { eş zamansızlığa tolerans, zaman, } \\
\text { olumlu ilişkiler ve güçlü yönlere } \\
\text { dayalı bir yaklaşım kullanımı } \\
\text { şeklinde ifade edilmiştir. }\end{array}$ \\
\hline $\begin{array}{l}\text { Besnoy ve } \\
\text { diğerleri (2015) }\end{array}$ & $\begin{array}{l}\text { İKF çocuğu olan ebeveynlerin } \\
\text { çocuklarını desteklemedeki } \\
\text { deneyimlerinin belirlenmesi }\end{array}$ & $\begin{array}{l}\text { 1'i OSB/ÖY ve 3'ü } \\
\text { Asperger/ÖY olan } \\
\text { toplam } 6 \text { İKF } \\
\text { öğrencinin } \\
\text { ebeveynleri }(n=8)\end{array}$ & Nitel & Görüşme Formu & $\begin{array}{l}\text { Ebeveynler çocuklarının } \\
\text { potansiyellerini maksimum düzeyde } \\
\text { kullanmalarını, gereksinimleriyle } \\
\text { sınırlı kalmamalarını istemektedir. } \\
\text { Ancak İKF üzerine yeterli kaynak } \\
\text { bulamadıkları için başarılı bir } \\
\text { savunucu olamadıklarını ifade } \\
\text { etmişlerdir. }\end{array}$ \\
\hline $\begin{array}{l}\text { Cain, Kaboski ve } \\
\text { Gilger (2019) }\end{array}$ & $\begin{array}{l}\text { İKF öğrencilerin boylamsal } \\
\text { verileri üzerinden ikincil } \\
\text { analizler yapılarak akademik } \\
\text { performanslarındaki değişim ve } \\
\text { sunulan hizmetlerin etkilerinin } \\
\text { araştırılması }\end{array}$ & $\begin{array}{l}147 \text { OSB/ÖY öğrenci } \\
549 \text { OSB öğrenci }\end{array}$ & Nicel & WJ-III & $\begin{array}{l}\text { İKF öğrenciler yüksek akademik } \\
\text { performans göstermektedir. Bu } \\
\text { performans zaman bağlı olarak } \\
\text { gelişim göstermekle birlikte hem } \\
\text { sadece OSB olan akranlarından hem } \\
\text { de birçok beceride tipik gelişim } \\
\text { gösteren akranlarından daha fazla } \\
\text { gelişim gösterdikleri belirlenmiştir. }\end{array}$ \\
\hline $\begin{array}{l}\text { Cederberg, Gann, } \\
\text { Foley-Nicpon ve } \\
\text { Sussman (2018) }\end{array}$ & $\begin{array}{l}\text { OSB tanılamasında kullanılan } \\
\text { iki aracın OSB/ÖY öğrencilerin } \\
\text { belirlenmesinde } \\
\text { kullanılabilirliğinin belirlenmesi }\end{array}$ & $\begin{array}{l}\text { Çocukları OSB/ÖY } \\
\text { tanısı almış } 23 \\
\text { ebeveyn }\end{array}$ & Nicel & $\begin{array}{l}\text { Social Responsiveness Scale } \\
\text { (SRS) } \\
\text { Autism Spectrum Screening } \\
\text { Questionnarie (ASSQ) }\end{array}$ & $\begin{array}{l}\text { Kullanılan iki aracın OSB/ÖY } \\
\text { öğrenciler üzerinde tutarsız olduğu } \\
\text { belirlenmiştir. Ancak bazı alt } \\
\text { testlerde belirgin farklılıklar } \\
\text { belirlenmiştir. Bu farklılıkların } \\
\text { tanılama ve müdahalede dikkate } \\
\text { alınabileceği ifade edilmiştir. }\end{array}$ \\
\hline
\end{tabular}




\begin{tabular}{|c|c|c|c|c|c|}
\hline $\begin{array}{l}\text { Doobay, Foley- } \\
\text { Nicpon, Ali ve } \\
\text { Assouline (2014) }\end{array}$ & $\begin{array}{l}\text { ÖY olan ve olmayan OSB'li } \\
\text { bireylerin bilişsel, sosyal uyum } \\
\text { ve psikososyal işlevlerinin } \\
\text { incelenmesi }\end{array}$ & $\begin{array}{l}40 \text { OSB/ÖY öğrenci } \\
46 \text { ÖY öğrenci }\end{array}$ & Nicel & $\begin{array}{l}\text { WISC-IV ya da Wechsler Adult } \\
\text { Intelligence Scale (WAIS) -III } \\
\text { BASC-2 } \\
\text { Viveland-II }\end{array}$ & $\begin{array}{l}\text { OSB/ÖY öğrencilerin işlemleme } \\
\text { hızı, sosyal uyum ve psikososyal } \\
\text { işlevlerde kontrol grubuna kıyasla } \\
\text { daha düşük performans gösterdiği } \\
\text { belirlenmiştir. }\end{array}$ \\
\hline $\begin{array}{l}\text { Foley-Nicpon, } \\
\text { Doobay ve } \\
\text { Assouline (2010) }\end{array}$ & $\begin{array}{l}\text { Davranış değerlendirme ölçeği } \\
\text { kullanılarak OSB/ÖY bireylerin } \\
\text { ebeveyn, öğretmen ve öz } \\
\text { değerlendirme sonuçlarının } \\
\text { belirlenmesi }\end{array}$ & $\begin{array}{l}54 \text { OSB/ÖY birey } \\
52 \text { ebeveyn } \\
42 \text { öğretmen }\end{array}$ & Nicel & BASC-2 & $\begin{array}{l}\text { Öz değerlendirme sonuçlarının } \\
\text { normal aralıkta olmasına karşın } \\
\text { ebeveyn ve öğretmen } \\
\text { değerlendirmelerinde psikososyal } \\
\text { işlevlerde yetersizlikler olduğu } \\
\text { belirlenmiştir. OSB/ÖY bireylerde } \\
\text { psikososyal işlevlerin etkilendiği } \\
\text { sonucuna ulaşılmıştır. }\end{array}$ \\
\hline $\begin{array}{l}\text { Foley-Nicpon, } \\
\text { Assouline ve } \\
\text { Stinson (2012) }\end{array}$ & $\begin{array}{l}\text { OSB/ÖY olan ve Asperger/ÖY } \\
\text { olan öğrencilerin bilişsel ve } \\
\text { akademik profillerinin } \\
\text { incelenmesi }\end{array}$ & $\begin{array}{l}18 \mathrm{OSB} / \mathrm{ÖY} \\
21 \text { Asperger/ÖY } \\
\text { öğrenci }\end{array}$ & Nicel & $\begin{array}{l}\text { ADI-R } \\
\text { ADOS } \\
\text { WISC-IV } \\
\text { WJ-III }\end{array}$ & $\begin{array}{l}\text { Asperger tanılı öğrenciler sözel } \\
\text { anlama indeksinde daha yüksek } \\
\text { puanlar alırken OSB tanılı ögrenciler } \\
\text { matematiksel akıcılık ve yazılı ifade } \\
\text { testlerinde daha yüksek puanlar } \\
\text { almışlardır. }\end{array}$ \\
\hline $\begin{array}{l}\text { Foley-Nicpon, } \\
\text { Assouline ve } \\
\text { Fosenburg (2015) }\end{array}$ & $\begin{array}{l}\text { Bilişsel beceriler ve eğitsel } \\
\text { hizmetler çerçevesinde IKFF } \\
\text { öğrencilerin benlik kavramı } \\
\text { profillerinin incelenmesi }\end{array}$ & $\begin{array}{l}53 \text { OSB/ÖY öğrenci } \\
11 \text { ÖÖG/ÖY öğrenci }\end{array}$ & Nicel & $\begin{array}{l}\text { WISC-IV } \\
\text { Piers Harris-2 (PH-2) }\end{array}$ & $\begin{array}{l}\text { İKF öğrencilerin benlik kavramı } \\
\text { profilleri normal aralıkta } \\
\text { belirlenmiştir. Bu durum yüksek } \\
\text { bilişsel yeteneklerin koruyucu bir } \\
\text { mekanizma sağladığı ya da } \\
\text { öğrencilerin pozitif bir yanılgıya } \\
\text { sahip olduğu şeklinde } \\
\text { yorumlanmıştır. }\end{array}$ \\
\hline $\begin{array}{l}\text { Foley-Nicpon, } \\
\text { Fosenburg, } \\
\text { Wurster ve } \\
\text { Assouline (2017) }\end{array}$ & $\begin{array}{l}\text { İki farklı ölçme aracının } \\
\text { OSB/ÖY ögrencileri DSM-V } \\
\text { kriterlerine göre tanılayabilme } \\
\text { düzeylerinin incelenmesi }\end{array}$ & $\begin{array}{l}16 \text { OSB/ÖY } \\
17 \text { Asperger/ÖY }\end{array}$ & Nicel & $\begin{array}{l}\text { ADI-R } \\
\text { ADOS }\end{array}$ & $\begin{array}{l}\text { İki ölçme aracından birisi tek başına } \\
\text { kullanıldığında öğrencilerin \%62’si } \\
\text { DSM-V ölçütlerine göre tanılanırken } \\
\text { iki araç birlikte kullanıldığında }\end{array}$ \\
\hline
\end{tabular}


öğrenci

\begin{tabular}{|c|c|c|c|c|c|}
\hline $\begin{array}{l}\text { Kuo, Maker, Su ve } \\
\mathrm{Hu}(2010)\end{array}$ & $\begin{array}{l}\text { Özel yetenekli öğrenciler için } \\
\text { geliştirilen zenginleştirme } \\
\text { programının tanılama modelinin } \\
\text { tanıtılması ve öğrencilerin } \\
\text { performanslarının analiz } \\
\text { edilmesi }\end{array}$ & $\begin{array}{l}50 \text { ÖY öğrenci } \\
\text { 3'ü OSB'li toplam } 11 \\
\text { İKF öğrenci }\end{array}$ & Karma & $\begin{array}{l}\text { The Gifted Traits Checklist for } \\
\text { Preschool Children (GTCPC) } \\
\text { Ebeveyn Görüşme Formu } \\
\text { Çocuk Gözlem Formu } \\
\text { Test of Nonverbal Intelligence } \\
\text { (TONI) - } 2 \\
\text { Wechsler Preschool and } \\
\text { Primary Scale of Intelligence } \\
\text { (WPPSI) - R }\end{array}$ & $\begin{array}{l}\text { OSB/ÖY olan öğrenciler gruba uyum } \\
\text { sağlama ve sosyal beceri alanlarında } \\
\text { dikkate değer gelişmeler } \\
\text { göstermiştir. }\end{array}$ \\
\hline $\begin{array}{l}\text { Melogno, Pinto ve } \\
\text { Levi (2015) }\end{array}$ & $\begin{array}{l}\text { OSB/ÖY olan bir öğrencinin dil } \\
\text { ve üst dil becerileri profilinin } \\
\text { belirlenmesi }\end{array}$ & 1 OSB/ÖY öğrenci & Vaka Analizi & $\begin{array}{l}\text { ADOS } \\
\text { Krug Asperger Disorder Index } \\
\text { (KADI) } \\
\text { WISC-III } \\
\text { NEPSY-II }\end{array}$ & $\begin{array}{l}\text { Öğrencinin üst dil farkındalığının } \\
\text { bazı alanlarında güçlükler yaşadığı } \\
\text { belirlenmiştir. }\end{array}$ \\
\hline $\begin{array}{l}\text { Neumeister, Yssel } \\
\text { ve Burney (2013) }\end{array}$ & $\begin{array}{l}\text { Ebeveynlerin İKF öğrencilerin } \\
\text { akademik başarısı üzerinde } \\
\text { oynadıkları role ilişkin } \\
\text { algılarının belirlenmesi }\end{array}$ & $\begin{array}{l}\text { 2'si OSB/ÖY olan } \\
\text { toplam } 10 \text { İKF } \\
\text { ögrrencinin anneleri }\end{array}$ & Nitel & Görüşme Formu & $\begin{array}{l}\text { Anneler, İKF öğrencilerin akademik } \\
\text { başarısında önemli bir rol } \\
\text { oynadıklarını belirtmişlerdir. } \\
\text { Çocuklarının hem ÖY hem de özel } \\
\text { gereksinimlerinin farkında olarak } \\
\text { potansiyellerinin gelişiminde önemli } \\
\text { bir sorumluluk üstlendiklerini ifade } \\
\text { etmişlerdir. }\end{array}$ \\
\hline
\end{tabular}




\begin{tabular}{|c|c|c|c|c|c|}
\hline $\begin{array}{l}\text { Rubenstein, } \\
\text { Schelling, } \\
\text { Wilczynski ve } \\
\text { Hooks (2015) }\end{array}$ & $\begin{array}{l}\text { OSB/ÖY öğrencilerin } \\
\text { ebeveynlerinin yaşadığ1 } \\
\text { deneyimlerin belirlenmesi }\end{array}$ & $\begin{array}{l}\text { OSB/ÖY çocuğu olan } \\
12 \text { ebeveyn }\end{array}$ & Nitel & Görüşme Formu & $\begin{array}{l}\text { Ebeveynler çocuklarının } \\
\text { ihtiyaçlarına uygun eğitsel hizmetleri } \\
\text { bulmada güçlükler yaşadıklarını, } \\
\text { çocuklarının okul ortamında } \\
\text { yaşadıkları güçlükler nedeniyle } \\
\text { uygun eğitim ortamları tasarlama ve } \\
\text { bulmada aktif rol aldıklarını ifade } \\
\text { etmişlerdir. }\end{array}$ \\
\hline $\begin{array}{l}\text { Willard-Holt, } \\
\text { Weber, Morrison } \\
\text { ve Horgan (2013) }\end{array}$ & $\begin{array}{l}\text { İKF öğrencilere yönelik } \\
\text { öğrenme stratejilerine ilişkin } \\
\text { İKF öğrencilerin bakış } \\
\text { açılarının belirlenmesi }\end{array}$ & $\begin{array}{l}\text { 5'i OSB/ÖY olan } \\
\text { toplam } 16 \text { İKF } \\
\text { öğrenci }\end{array}$ & Karma & $\begin{array}{l}\text { Possibilities for Learning survey } \\
\text { (PFL) } \\
\text { Görüşme Formu }\end{array}$ & $\begin{array}{l}\text { İKF öğrenciler zayıf yönlerinin } \\
\text { üstesinden gelebilmek için güçlü } \\
\text { yönlerini kullanabilmelerine rağmen } \\
\text { genel okul deneyimlerinin } \\
\text { potansiyellerini öğrenme noktasında } \\
\text { yardımcı olmadığını ifade } \\
\text { etmişlerdir. }\end{array}$ \\
\hline $\begin{array}{l}\text { Wu, Lo ve Tsai } \\
\text { (2019) }\end{array}$ & $\begin{array}{l}\text { OSB/ÖY öğrenciler için olumlu } \\
\text { eğitim stratejilerinin } \\
\text { belirlenmesi }\end{array}$ & 2 OSB/ÖY öğrenci & Vaka Analizi & PFL & $\begin{array}{l}\text { Öğretmenler, okul yönetici ve } \\
\text { ebeveynler için etkili olabilecek } \\
\text { çeșitli stratejiler belirlenmiştir. }\end{array}$ \\
\hline
\end{tabular}

Not. BAYGB= Başka Türlü Adlandırılamayan Yaygın Gelişimsel Bozukluk; İKF= İki Kere Farklı; OSB= Otizm Spektrum Bozukluğu; ÖY= Özel Yetenek 


\section{BULGULAR}

İncelenen çalışmaların amaçları ve temel bulguları bu araştırmanın temalarını oluşturmuştur. Araştırmanın temalarını oluşturan çalışmalar aşağıdaki şekilde verilmiştir.

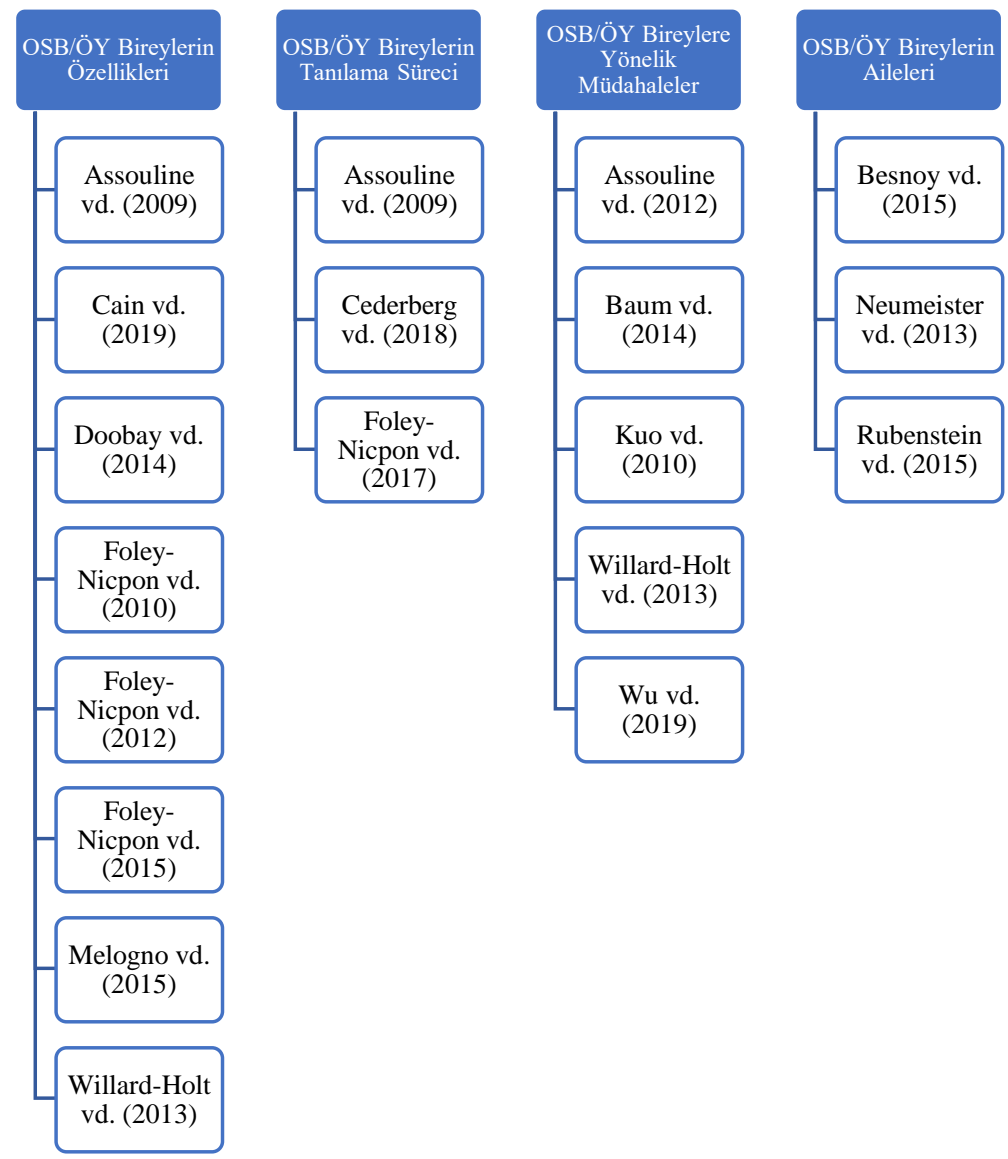

Şekil 2. Temaları Oluşturan Çalışmalar

\subsection{OSB/ÖY Bireylerin Özellikleri}

OSB'li iki kere farklı bireyler ile yürütülen ve akademik başarı açısından veri sağlayan çalışmalar incelendiğinde, bu bireylerin hem birçok beceride tipik gelişim gösteren akranlarından hem de sadece OSB olan akranlarından daha yüksek akademik başarı sergiledikleri görülmektedir. Cain ve diğerleri (2019) yürüttükleri çalışmada, iki kere farklı öğrencilerin akademik performanslarındaki değişimi boylamsal olarak incelemişlerdir. Araştırmada OSB/ÖY olan öğrencilerin yüksek akademik performans sergilediği, zamana bağlı olarak bu performansta artış gözlemlendiği ve hem sadece OSB olan hem de tipik gelişim gösteren akranlarından daha fazla gelişim gösterdikleri belirlenmiştir.

Bilișsel beceriler açısından bir değerlendirme yapıldığında OSB/ÖY bireylerin birçok beceride ÖY olan bireylere yakın bir performans sergiledikleri görülmektedir. Örneğin Assouline ve diğerleri (2009) zekâ puanı 145 IQ üzerinde belirlenmiş, birisi OSB olan iki öğrencinin profillerini karşılaştırdıkları çalışmada WISC-IV ölçeğinin işlemleme hızı indeksi dışında anlamlı bir farklılık olmadığını belirlemişlerdir. OSB/ÖY olan bireylerin işlemleme hızında ÖY olan akranlarına nazaran daha zayıf olduklarını belirleyen farklı araştırmalar da bulunmaktadır (Doobay ve diğerleri, 2014; Foley-Nicpon ve diğerleri, 2012). Bunun yanında OSB/ÖY olan bireylerin sadece ÖY olan bireylere oranla dil becerileri ve yürütücü işlevler açısından daha düşük 
performans sergiledikleri belirtilmektedir (Assouline ve diğerleri, 2009; Melogno ve diğerleri, 2015).

OSB/ÖY olan bireylerin, OSB'nin doğasıyla uyumlu bir şekilde, sadece ÖY olan akranlarından sosyal beceriler, sosyal uyum ve psikososyal işlevlerde farklılaştıkları belirtilmektedir (Assouline ve diğerleri, 2009; Doobay ve diğerleri, 2014). Foley-Nicpon ve diğerleri (2010) yürüttükleri çalışmada psikososyal işlevlerin aile ve öğretmen değerlendirmelerinde dikkat problemleri, atipiklik, depreson, hiperaktivite, günlük yaşam becerileri ve sosyal beceriler alt testlerinde anlamlı farklılıklar belirlendiği ifade edilmektedir. Ancak araştırmada psikososyal işlevler, öz değerlendirme yoluyla değerlendirildiğinde anlamlı bir farklılaşma tespit edilmediği belirtilmiştir. Benzer bir durum Foley-Nicpon ve diğerlerinin (2015) iki kere farklı ögrencilerin benlik kavramı profillerini belirlemek amacıyla yürüttükleri çalışmada da görülmüştür. İki kere farklı bireylerin benlik kavramlarının normal sınırlar içerisinde belirlendiği rapor edilen çalışmada, bu durumun sebebi olarak iki kere farklı bireylerin güçlü bilişsel becerilerinden kaynaklanan pozitif bir yanılgıya sahip olabilecekleri şeklinde yorum yapılmıştır. Nitekim bir başka çalışmada, iki kere farklı öğrencilerin zayıf yönlerinin üstesinden gelebilmek için güçlü yönlerini kullandıkları belirlenmiştir (Willard-Holt ve diğerleri, 2013).

Özetle, OSB olan iki kere farklı bireylerin birçok bilişsel ve akademik beceri alanında ortalama üzerinde performans sergileyebildikleri görülmektedir. Bunun yanında işlemleme hızı, yürütücü işlevler, dil becerileri, sosyal beceriler, sosyal uyum ve psikososyal işlevler açısından sadece ÖY olan akranları düzeyinde performans sergileyemedikleri bildirilmektedir.

\subsection{OSB/ÖY Bireylerin Tanılama Süreci}

OSB/ÖY bireylerin gerek akademik becerilerde gerekse bilişsel becerilerde tipik gelişim gösteren akranlarından daha yüksek performans sergilemesi tanılama süreçlerini güçleştiren bir durum olarak karşımıza çıkmaktadır. Özellikle ÖY değerlendirmelerinde sadece bilişsel beceri değerlendirmesi yapılması OSB olan bireylerin fark edilememesine sebep olabilecektir. Assouline ve diğerleri (2009) bu bireylerin tanılama süreçlerinde, bilişsel performans yanında OSB tanısı için ek ölçüt ve araçların kullanılması gerektiğini ifade etmektedir. Fakat OSB tanılamasında kullanılan araçların OSB/ÖY öğrenciler üzerinde tutarsız sonuçlar verdiğini belirleyen araştırmalar bulunmaktadır (Cederberg ve diğerleri, 2018). Örneğin OSB tanılamasında kullanılan iki ölçme aracının OSB/ÖY olan öğrencileri DSM-V kriterlerine göre tanılayabilme düzeylerini incelemek amacıyla yürütülen bir çalışmada araçlardan birisi tek başına kullanıldığında \%62 olan tanılama oranının iki araç birlikte kullanıldığında \%100'e ulaştığı belirtilmiştir (Foley-Nicpon ve diğerleri, 2017).

Özetle, tanılama süreçlerinde kullanılan araçların iki kere farklı bireyleri ayırt etmede güçlü sonuçlar veremediği bildirilmektedir. Dolayısıyla ÖY değerlendirmelerine OSB değerlendirmesinin eklenmesi yanında OSB'nin de çoklu yaklaşımlarla incelenmesi gerektiği görülmektedir.

\subsection{OSB/ÖY Bireylere Yönelik Müdahaleler}

İki kere farklı öğrenciler tipik gelişim gösteren akranlarından farklılaşan ihtiyaçları doğrultusunda eğitim hizmetlerine ihtiyaç duymaktadır. Formal eğitim süreçlerinin bu öğrencilerin potansiyellerini geliştirme noktasında yeterli olmadığ görülmektedir (Willard-Holt ve diğerleri, 2013). Benzer şekilde sadece ÖY programlarının da bu öğrencilerin gelişiminde yeterli olmayabildiği ifade edilmektedir (Assouline ve diğerleri, 2012). Bu doğrultuda OSB/ÖY olan öğrencilerin farklı yaklaşımlara ihtiyaç duydukları görülmektedir.

Baum ve diğerleri (2014) yürüttükleri çalışmada iki kere farklı öğrencilerin güçlü yönlerine dayalı bir eğitim sistemi olan okuldan mezun olan öğrencilerin bilişsel, sosyal ve duygusal/davranışsal alanlarda gelişim gösterdiklerini belirlemişlerdir. Bu gelişimin altında yatan beş temel faktörün psikolojik güvenlik, eş zamansızlığa tolerans, olumlu ilişkiler ve güçlü yönlere dayalı bir eğitim yaklaşım olduğu ifade edilmiştir. ÖY öğrenciler için geliştirilen bir 
zenginleştirme programının tanıtıldığı bir başka çalışmada (Kuo ve diğerleri, 2010) iki kere farklı öğrencilerin gruba uyum sağlama ve sosyal beceri alanlarında önemli gelişmeler gösterdikleri belirlenmiştir. Wu ve diğerleri (2019), iki kere farklı öğrencilerin olumlu öğrenme deneyimlerine sahip olabilmeleri için destekleyici okul ortamının gerekliliğinden bahsetmektedir. Destekleyici okul ortamı üç ana unsurdan oluşmaktadır. Bunlar müfredat esnekliği, güçlü yanlara odaklı bir yaklaşım ve güvenli çevredir.

Özetle, iki kere farklı bireylere sunulacak özel eğitim hizmetlerinin güçlü yanlara odaklanan bir yaklaşım izlenmesi gerektiği görülmektedir. Bununla birlikte, süreçte öğrencilerin gereksinimleri doğrultusunda uyarlamalar yapılması gerektiği de görülmektedir.

\subsection{OSB/ÖY Bireylerin Aileleri}

Ulaşılan araştırmalarda iki kere farklı bireylerin ebeveynlerinin eğitim-öğretim süreçlerinde aktif rol aldıkları, çocuklarının yetersizlikleriyle sınırlı kalmayıp potansiyellerinin geliştirilebilmesi için sürekli bir arayış içerisinde oldukları belirtilmektedir (Besnoy ve diğerleri, 2015; Neumeister ve diğerleri, 2013; Rubenstein ve diğerleri, 2015). Besnoy ve diğerleri (2015) yürüttükleri çalışmada, iki kere farklı çocuğu olan ebeveynlerin hem çocuklarının yetersizliklerinin üstesinden gelmek istediklerini hem de potansiyellerini geliştirmek istediklerini belirlemiştir. Ancak ebeveynler bu iki durumla baş edebilmek için yeterli bilgi ve kaynağa ulaşamadıklarını ifade etmişlerdir.

Neumeister ve diğerleri (2013) iki kere farklı çocuğu olan annelerin çocuklarının akademik başarısında önemli rol oynadıklarına yönelik bir algıya sahip olduklarını belirlemişlerdir. Bu algıda annelerin, çocuklarının yetenekleri ve yetersizliklerini kabul etmelerinin rol oynadığı ifade edilmiştir. Bunun yanında, çocuklarının potansiyellerinin geliştirilmesinin sorumluluğunu üstlenmeleri de önemli bir unsur olarak kabul edilmiștir. Araştırmada annelerin çocukları için profesyonel değerlendirmeleri aradıkları, uygun eğitsel desteklerin sağlanmasını güvence altına aldıkları ve bu süreçte nasıl bir savunucu olmaları gerektiğini öğrendikleri belirlenmiştir. Rubenstein ve diğerleri (2015) iki kere farklı çocuğu olan ebeveynler ile yürüttükleri çalışmada, ebeveynlerin çocuklarının özel gereksinimleri doğrultusunda uygun eğitim ortamlarını bulmakta güçlükler yaşadıkları belirlenmiştir. Araştırmada ebeveynler, çocuklarının özellikleri ve ihtiyaçları ile tipik gelişim gösteren akranlarının devam ettikleri eğitim programlarının uyumsuz olduklarını fark ettiklerini ifade etmişlerdir. Bu durumun, ebeveynlerin çocuklarına uygun eğitim ortamlarını bulma ya da oluşturma konusunda aktif rol almalarına sebep olduğu belirtilmiştir.

Özetle iki kere farklı bireylerin ebeveynleri, çocuklarının yeteneklerini geliştirmek ve yetersizlikleri ile baş ederek bağımsız bireyler olmalarını sağlamak istemektedirler. Ancak uygun eğitim hizmetlerine ve doğru kaynaklara ulaşmakta güçlükler yaşadıkları görülmektedir.

\section{TARTIŞMA, SONUÇ VE ÖNERILER}

$\mathrm{Bu}$ araştırmada OSB/ÖY olan ögrencilere yönelik ulusal ve uluslararası alanyazında yer alan çalışmalar sistematik olarak analiz edilmiştir. Bu doğrultuda ERIC, ProQuest, ULAKBİM ve DergiPark veri tabanlarında taramalar yapılmış, dahil etme ve dışlama kriterleri çerçevesinde 17 araştırma belirlenmiştir. Ulaşılan çalışmalar OSB/ÖY olan bireylerin özellikleri, OSB/ÖY olan bireylerin tanılama süreci, OSB/ÖY bireylere yönelik müdahaleler ve OSB/ÖY bireylerin ailelerinin yaşadıkları güçlükler temaları altında incelenmiştir.

Ulaşılan çalışmalarda OSB/ÖY olan bireylerin akademik başarı anlamında tipik gelişim gösteren ve OSB olan akranlarından daha yüksek performans sergiledikleri (Cain ve diğerleri, 2019), bilişsel becerilerin birçoğunda ÖY olan akranlarıyla benzer bir performans sergiledikleri belirlenmiştir (Assouline ve diğerleri, 2009). Bu bireylerin güçlük yaşadıkları alanlar işlemleme hızı, yürütücü işlevler, dil becerileri, sosyal beceriler, sosyal uyum ve psikososyal işlevler olarak gösterilmektedir (Assouline ve diğerleri, 2009; Doobay ve diğerleri, 2014; Foley-Nicpon ve 
diğerleri, 2010; Foley-Nicpon ve diğerleri, 2012; Melogno ve diğerleri, 2015). Dolayısıyla OSB olan iki kere farklı öğrencilerin güçlü akademik ve bilişsel becerilere karşın zayıf sosyaliletişimsel beceriler sergileyebileceğinin bilinmesi gerekmektedir. Bu bireylerin güçlü ve zayıf yönlerinin bilinmesi, fark edilebilmeleri için bir gerekliliktir. Gerçekte iki kere farklı olan ancak bu şekilde tanılanmamış bir öğrencinin eğitim süreci içerisinde üç olası senaryonun görülmesi mümkündür. Bunların birincisi, öğrencinin yeteneklerinin ön plana çıkması nedeniyle yetersizliklerinin fark edilmemesi ve bu konuda bir destek alamamasıdır. İkincisi, yetersizlikleriyle ön plana çıkması ve bu konuda destek eğitim almasına karşın yetenekli olduğu alanlara yönelik herhangi bir destek alamamasıdır. Üçüncüsü ise, yetenek ve yetersizliklerinin birbirini maskeleyerek herhangi bir tanı almayıp tipik gelişim gösteren akranlarıyla eğitim sürecine devam etmesidir. Alanyazında maskeleme olarak adlandırılan (Reis ve diğerleri, 2014) bu durum iki kere farklı bir öğrencinin potansiyelini kullanabilmesi ve yetersizlikleriyle baş ederek bağımsız bir birey olması önünde engel teşkil edebilmektir. Dolayısıyla ÖY olan bir bireyin aynı zamanda OSB olabileceğinin bilinmesi gerekmektedir. Ayrıca bu iki durumun bir arada görülmesiyle bireylerin nasıl özellikler sergileyebileceği konusunda tanılamadeğerlendirme süreçlerinde çalışan uzmanların, öğretmenlerin ve ailelerin bilgilendirilmesi gerektiği düşünülmektedir.

İki kere farklı bir bireyin nasıl özellikler sergileyecebileceğini bilmek doğru bir tanılama süreci için gerekli olmakla birlikte yeterli değildir. Çünkü tanılama süreçlerinde güçlü ölçme araçlarına ihtiyaç duyulmaktadır. Ulaşılan çalışmalarda ÖY tanılama süreçlerine OSB değerlendirmesi eklenmesinin gerekliliği ifade edilmektedir (Assouline ve diğerleri, 2009). Ancak OSB değerlendirmesinde kullanılan araçların OSB/ÖY olan bireyleri ayırt etmede tutarsız sonuçlar verebildiği görülmektedir (Cederberg ve diğerleri, 2018; Foley-Nicpon ve diğerleri, 2017). Dolayısıyla etkili bir tanılama süreci için birden çok aracı içeren, çoklu değerlendirme yaklaşımlarının gerekli olduğu düşünülmektedir. $\mathrm{Bu}$ durum tanılama ve değerlendirme süreçlerinde yer alan uzmanların hem OSB hem de ÖY değerlendirmeleri konusunda eğitimler alması gerekliliğini (Foley-Nicpon ve diğerleri 2011; Henderson, 2001) bir kez daha göstermektedir. Nitekim ülkemizde de iki kere farklı öğrencileri ayırt edebilecek, tanılama süreçlerinde çalışan uzmanların sayısı oldukça kısıtlıdır (Leana-Taşcılar, 2017). Öte yandan kullanılan tanılama araçlarının bir kısmının standardizayon-norm çalışmalarının bulunmadığı görülmekte (Güngörmüş Özkardeş, 2013), ya da Wechsler Intelligence Scale for Children Revised (WISC-R) gibi bazı ölçme araçları, standardizasyon çalışmaları üzerinden uzun yıllar geçmiş olmasına rağmen (Savaşır ve Şahin, 1995) hala kullanılmakta ve sertifikasyon eğitimleri devam etmektedir. Dolayısıyla hem tanılama süreçlerinde kullanılan araçların niteliklerinin ve niceliklerinin arttırılmasına hem de iki kere farklı bireylerin özelliklerini temel alarak bu bireyleri belirlemeye yönelik geliştirilmiş geçerli ve güvenilir ölçme araçlarına gereksinim duyulmaktadır.

OSB/ÖY olan öğrencilere yönelik yürütülecek müdahale çalışmalarının etkili olabilmesi için öğrencilerin güçlü yönlerine odaklanan, aynı zamanda yetersizlikleriyle orantılı uyarlamalar içeren yaklaşımların benimsenmesi gerekmektedir (Baum ve diğerleri, 2014; Kuo ve diğerleri, 2010; Wu ve diğerleri, 2019). Alanyazında bu girişimlere örnek olabilecek araştırmaların kısıtlı sayıda oluşu dikkat çekicidir. Rubenstein ve diğerleri (2013) iki kere farklı bireylere uygun eğitsel hizmetlerin sağlanmasında yeterli kuramsal ve kanıta dayalı bilginin gerekliliğini ifade etmektedir. Bu doğrultuda hem yetersizliğe sahip hem de ÖY olan iki kere farklı öğrencilere yönelik uygun eğitim modellerinin geliştirilmesi ve bu konuda daha fazla araştırma yapılmasının önemli bir ihtiyaç olduğu görülmektedir. Nitekim bu bireylerin ebeveynleri de çocuklarına uygun eğitim ortamlarını bulma konusunda güçlükler yaşamaktadır (Besnoy ve diğerleri, 2015; Rubenstein ve diğerleri, 2015).

Türkiye'de konuyla ilgili yürütülen herhangi bir makaleye ulaşılamamış olması dikkat çekicidir. Konuya ilişkin ülkemizde yalnızca bir yüksek lisans tezi tespit edilebilmiştir (Ömür, 2019). Bu duruma, iki kere farklı bireylere yönelik tanılama araçlarının bulunmamasının neden olabileceği düşünülmektedir. Öte yandan tanılama süreçlerinde çalışan uzmanların kısıtll1ı̆̆ 1 ve 
iki kere farklılığa ilişkin bilgi düzeyinin yetersiz olması da bu duruma bir sebep olarak gösterilebilir. Bunun yanında gerek alandaki teorik ve pratik bilgi eksiklikleri gerekse farkındalık çalışmalarının yetersizliği de OSB olan iki kere farklı bireylerin fark edilebilmesi önünde engel oluşturmaktadır. Ayrıca ülkemizde iki kere farklı bireylere yönelik bir politika eksikliği de olduğu göze çarpmaktadır. Örneğin Özel Eğitim Hizmetleri Yönetmeliği’nde (2018) iki kere farklı bireylere ilişkin herhangi bir bilgi yer almamaktadır. Benzer şekilde ne Özel Yetenekliler Eğitimi Strateji ve Uygulama Kılavuzu'nda (MEB, 2013) ne de diğer özel gereksinimli öğrencilere yönelik hazırlanan programlar içerisinde iki kere farklı bireylere yönelik bir uyarlama ya da tanımlama yer almamaktadır (MEB, 2008a, 2008b). Dolayısıyla hem politika belirleyicilerin hem de araştırmacılar ve alan uzmanlarının konuyla ilgili çalışmalar yapmasının önemli bir gereklilik olduğu düşünülmektedir.

Sonuç olarak, bu araştırmada ulaşılan çalışmalardan OSB olan iki kere farklı öğrencilerin birçok bilişsel ve akademik beceride ortalama üzerinde performans sergiledikleri ancak sosyaliletişimsel becerilerde güçlükler yaşadıkları belirlenmiştir. Bu tutarsız performans örüntüleri tanılama süreçlerini güçleştiren bir unsur olarak karşımıza çıkmaktadır. Nitekim tanılama süreçlerinde kullanılan araçların da OSB/ÖY olan bireyleri ayırt etmede etkili sonuçlar veremediği görülmektedir. Sonuçlar müdahale yaklaşımları açısından değerlendirildiğinde, etkili müdahale yaklaşımlarının temelde bu bireylerin güçlü yanlarına odaklandıkları görülmektedir. Bunun yanında öğrencilerin gereksinimleri doğrultusunda uyarlamaların yapılması gerekmektedir. Araştırmanın sonuçlarının ortaklaştığı temel nokta, OSB olan iki kere farklı öğrencilere yönelik ulaşılabilen bilgilerin oldukça kısıtlı oluşudur. Bu durum hem tanılama hem de müdahale süreçlerinin gelişimine ket vurmaktadır. $\mathrm{Bu}$ doğrultuda, ileride yapılacak araştırmalar için öneriler aşağıda sıralanmıştır:

1- İki kere farklı bireylerin akademik, bilişsel ve sosyal profillerinin belirlenmesi için ileri araştırmaların yapılması gerekmektedir.

2- İki kere farklı bireyleri tanılamak amacıyla, bu bireylerin özelliklerini temel alan kuramsal yaklaşımlar çerçevesinde ölçme araçları geliştirilmelidir.

3- Güçlü teorik ve kanıt temelli araştırmalarla aileler, eğitimciler ve diğer alan uzmanlarının ihtiyaç duydukları bilgiler sağlanmalıdır.

Ek olarak elde edilen sonuçlar çerçevesinde uygulamaya yönelik bazı öneriler sunulabilir. Uygulamaya yönelik öneriler aşağıda sıralanmıştır:

1- Tanılama süreçelerinde çoklu değerlendirme yaklaşımları benimsenmeli, tek bir araç kullanılarak yapılan tanılama işlemlerinden kaçınılmalıdır.

2- Tanılamada kullanılan araçların geçerli ve güvenilir olmasına dikkat edilmelidir.Tanılama süreçlerinde çalışan uzmanların, eğitimcilerin ve ailelerin iki kere farklılığa ilişkin bilgi sahibi olması sağlanmalı ve bu doğrultuda farkındalık çalışmaları yürütülmelidir.

3- Uygulanan müdahale çalışmalarında merkeze öğrencinin güçlü olduğu alan ya da alanlar alınmalıdır. Bunun yanında müdahale sürecinde öğrencinin gereksinimleri doğrultusunda uyarlamalar yapılmalıdır.

4- İki kere farklılık kavramı MEB tarafından ele alınmalı, programlar içerisinde bu bireylere özgü uyarlamalar için firsat sağlanmalıdır.

\section{KAYNAKÇA}

Amend, E. R. (2018). Finding hidden potential: Toward best practices in identifyin gifted students with disabilities. In S. B. Kaufman (Ed.), Twice exceptional: supporting and educating bright and creative students with learning difficulties (pp. 66-82). New York, NY: Oxford University Press. 
American Psychiatric Association. (2013). Diagnostic and statistical manual of mental disorders (5th ed.). https://doi.org/10.1176/appi.books.9780890425596

Assouline, S. G., Foley-Nicpon, M., \& Doobay, A. (2009). Profoundly gifted girls and autism spectrum disorder: A psychometric case study comparison. Gifted child quarterly, 53(2), 89-105. https://doi.org/10.1177/0016986208330565

Assouline, S. G., Foley-Nicpon, M., \& Dockery, L. (2012). Predicting the academic achievement of gifted students with autism spectrum disorder. Journal of autism and developmental disorders, 42(9), 1781-1789. https://doi.org/10.1007/s10803-011-1403-x

Baldwin, L., Baum, S., Pereles, D., \& Hughes, C. (2015). Twice-exceptional learners: The journey toward a shared vision. Gifted Child Today, 38(4), 206-214. https://doi.org/10.1177/1076217515597277

Baum, S. M., \& Owen, S. V. (2004). To be gifted and learning disabled: Meeting the needs of gifted students with LD, ADHD, and more. Mansfield Center, CT: Creative Learning Press.

Baum, S. M., Rizza, M., \& Renzulli, S. (2006). Twice exceptional adolescents: Who are they? What do they need? In F. A. Dixon, \& S. M. Moon (Eds.), The handbook of secondary gifted education (pp. 137-164). Waco, TX: Prufrock Press.

Baum, S. M., Schader, R. M., \& Hébert, T. P. (2014). Through a different lens: Reflecting on a strengths-based, talent-focused approach for twice-exceptional learners. Gifted Child Quarterly, 58(4), 311-327. https://doi.org/10.1177/0016986214547632

Baykoç Dönmez, N. (2017). Üstün ve özel yetenekli çocuklar ve eğitimleri. In N. Baykoç Dönmez (Ed.), Özel gereksinimli çocuklar ve özel eğitim (pp. 359-385). Ankara: Eğiten Kitap.

Beckmann, E., \& Minnaert, A. (2018). Non-cognitive characteristics of gifted students with learning disabilities: An in-depth systematic review. Frontiers in Psychology, 9, 504. https://doi.org/10.3389/fpsyg.2018.00504

Besnoy, K. D., Swoszowski, N. C., Newman, J. L., Floyd, A., Jones, P., \& Byrne, C. (2015). The advocacy experiences of parents of elementary age, twice-exceptional children. Gifted Child Quarterly, 59(2), 108-123. https://doi.org/10.1177/0016986215569275

Cain, M. K., Kaboski, J. R., \& Gilger, J. W. (2019). Profiles and academic trajectories of cognitively gifted children with autism spectrum disorder. Autism, 23(7), 1663-1674. https://doi.org/10.1177/1362361318804019

Cederberg, C. D., Gann, L. C., Foley-Nicpon, M., \& Sussman, Z. (2018). ASD Screening measures for high-ability youth with ASD: Examining the ASSQ and SRS. Gifted Child Quarterly, 62(2), 220-229. https://doi.org/10.1177/0016986217752098

Conejeros-Solar, M. L., Gómez-Arizaga, M. P., Schader, R. M., Baum, S. M., SandovalRodríguez, K., \& Henríquez, S. C. (2021). The other side of the coin: Perceptions of twice-exceptional students by their close friends. SAGE Open, 11(2), 1-11. https://doi.org/10.1177\%2F21582440211022234

Doobay, A. F., Foley-Nicpon, M., Ali, S. R., \& Assouline, S. G. (2014). Cognitive, adaptive, and psychosocial differences between high ability youth with and without autism spectrum disorder. Journal of autism and developmental disorders, 44(8), 2026-2040. https://doi.org/10.1007/s10803-014-2082-1 
Foley-Nicpon, M., Doobay, A. F., \& Assouline, S. G. (2010). Parent, teacher, and self perceptions of psychosocial functioning in intellectually gifted children and adolescents with autism spectrum disorder. Journal of autism and developmental disorders, 40(8), 1028-1038. https://doi.org/10.1007/s10803-010-0952-8

Foley-Nicpon, M., Allmon, A., Sieck, B., \& Stinson, R. D. (2011). Empirical investigation of twice-exceptionality: Where have we been and where are we going?. Gifted Child Quarterly, 55(1), 3-17. https://doi.org/10.1177/0016986210382575

Foley-Nicpon, M., Assouline, S. G., \& Stinson, R. D. (2012). Cognitive and academic distinctions between gifted students with autism and asperger syndrome. Gifted Child Quarterly, 56(2), 77-89. https://doi.org/10.1177/0016986211433199

Foley-Nicpon, M., Assouline, S. G., \& Fosenburg, S. (2015). The relationship between selfconcept, ability, and academic programming among twice-exceptional youth. Journal of Advanced Academics, 26(4), 256-273. https://doi.org/10.1177/1932202X15603364

Foley-Nicpon, M., Fosenburg, S. L., Wurster, K. G., \& Assouline, S. G. (2017). Identifying high ability children with DSM-5 autism spectrum or social communication disorder: performance on autism diagnostic instruments. Journal of autism and developmental disorders, 47(2), 460-471. https://doi.org/10.1007/s10803-016-2973-4

Galbraith, J. (2018). Twice-exceptionality and social-emotional development. In S. B. Kaufman (Ed.), Twice exceptional: supporting and educating bright and creative students with learning difficulties (pp. 138-147). New York, NY: Oxford University Press.

Güngörmüş Özkardeş, O. (2013). Türkiye'de özel öğrenme güçlüğüne ilişkin yapılan araştırmaların betimsel analizi. Boğaziçi Üniversitesi Eğitim Dergisi, 30(2), 123-153. Retrieved from https://dergipark.org.tr/tr/pub/buje/issue/14782/327987

Henderson, L. M. (2001). Asperger's syndrome in gifted individuals. Gifted Child Today, 24(3), 28-35. https://doi.org/10.4219/gct-2001-541

Huber, D. H. (2007). Clinical presentation of autistic spectrum disorder in intellectual gifted students (Unpublished doctoral dissertation). University of Lowa, Lowa City.

Kuo, C. C., Maker, J., Su, F. L., \& Hu, C. (2010). Identifying young gifted children and cultivating problem solving abilities and multiple intelligences. Learning and Individual Differences, 20(4), 365-379. https://doi.org/10.1016/j.lindif.2010.05.005

Leana-Taşcılar, M. Z. (2017). İki kez özel öğrencilerin eğitim programları nasıl olmalıdır. S. Demir (Ed.), Özel yeteneklilerin eğitiminde program tasarımı içinde (ss. 301-326). Ankara: Pegem Akademi.

McCoach, D. B., Kehle, T. J., Bray, M. A., \& Siegle, D. (2001). Best practices in the identification of gifted students with learning disabilities. Psychology in the Schools, 38(5), 403-411. https://doi.org/10.1002/pits.1029

Melogno, S., Pinto, M. A., \& Levi, G. (2015). Profile of the linguistic and metalinguistic abilities of a gifted child with autism spectrum disorder: A case study. Child Language Teaching and Therapy, 31(1), 113-126. https://doi.org/10.1177/0265659014530414

Milli Eğitim Bakanlığı. (2008a). Yaygın gelişimsel bozukluklar destek eğitim programı. Retrieved from http://ookgm.meb.gov.tr/meb_iys_dosyalar/2014_02/14114042_ygbdep.pdf 
Milli Eğitim Bakanlığı. (2008b). Özel öğrenme güçlüğü destek eğitim programı. Retrieved from http://ookgm.meb.gov.tr/meb_iys_dosyalar/2014_02/14114042_oogdep.pdf

Milli Eğitim Bakanlığı. (2013). Özel yetenekli bireylerin eğitimi strateji ve uygulama kılavuzu. Retrieved from https://orgm.meb.gov.tr/meb_iys_dosyalar/2013_11/25034903_zelyeteneklibireylerineit imistratejiveuygulamaklavuzu.pdf

Neumeister, K. S., Yssel, N., \& Burney, V. H. (2013). The influence of primary caregivers in fostering success in twice-exceptional children. Gifted Child Quarterly, 57(4), 263-274. https://doi.org/10.1177/0016986213500068

Ömür, N. (2019). Üstün zekâlı otizm spektrum bozukluğu (OSB) olan çocukların özellikleri, davranışlar ve ĕgitim gereksinimlerinin temellendirilmiş teoriyle belirlenmesi (Yayımlanmamış yüksek lisans tezi). Anadolu Üniversitesi Eğitim Bilimleri Enstitüsü, Eskişehir.

Özel Eğitim Hizmetleri Yönetmeliği. (2018, 7 Temmuz). Resmi Gazete (Sayı: 30471). Erişim Adresi:

https://orgm.meb.gov.tr/meb_iys_dosyalar/2018_07/09101900_ozel_egitim_hizmetleri_ yonetmeligi_07072018.pdf

Pfeiffer, S. I., \& Foley-Nicpon, M. (2018). Knowns and unknowns about students with disabilities who also happen to be intellectually gifted. In S. B. Kaufman (Ed.), Twice exceptional: supporting and educating bright and creative students with learning difficulties (pp. 105119). New York, NY: Oxford University Press.

Reis, S. M., Baum, S. M., \& Burke, E. (2014). An operational definition of twice-exceptional learners: Implications and applications. Gifted Child Quarterly, 58(3), 217-230. https://doi.org/10.1177/0016986214534976

Ruban, L. M., \& Reis, S. M. (2005). Identification and assessment of gifted students with learning disabilities. Theory into Practice, 44(2), 115-124. https://doi.org/10.1207/s15430421tip4402_6

Rubenstein, L. D., Pierson, E. E., Wilczynski, S. M., \& Connolly, S. C. (2013). Fitting the high ability program to the needs of individuals with autism spectrum disorders. Psychology in the Schools, 50(9), 910-922. https://doi.org/10.1002/pits.21719

Rubenstein, L. D., Schelling, N., Wilczynski, S. M., \& Hooks, E. N. (2015). Lived experiences of parents of gifted students with autism spectrum disorder: The struggle to find appropriate educational experiences. Gifted Child Quarterly, 59(4), 283-298. https://doi.org/10.1177/0016986215592193

Savaşır, I., \& Şahin, N. (1995). Wechsler çocuklar için zeka ölçeği (WISC-R). Ankara: Türk Psikologlar Derneği Yayınları.

Schultz, J. J. (2011). Nowhere to hide: Why kids with ADHD and LD hate school and what we can do about it. New york, NY: John Wiley \& Sons.

Vaughn, S. (1989). Gifted learning disabilities: Is it such a bright idea? Learning Disabilities Focus, 4(2), 123-128. Retrieved from https://psycnet.apa.org/record/1989-41349-001 
Weinfeld, R., Barnes-Robinson, L., Jeweler, S., \& Shevitz, B. (2002). Academic programs for gifted and talented/learning disabled students. Roeper Review, 24(4), 226-233. https://doi.org/10.1080/02783190209554185

Willard-Holt, C., Weber, J., Morrison, K. L., \& Horgan, J. (2013). Twice-Exceptional Learners' Perspectives on Effective Learning Strategies. Gifted Child Quarterly, 57(4), 247-262. https://doi.org/10.1177/0016986213501076

Wu, I.-C., Lo, C. O., \& Tsai, K.-F. (2019). Learning experiences of highly able learners with ASD: Using a success case method. Journal for the Education of the Gifted, 42(3), 216242. https://doi.org/10.1177/0162353219855681

Y1lmaz-Yenioğlu, B., ve Melekoğlu, M. A. (2020). Öğrenme güçlüğü ve özel yeteneği olan iki kere farklı bireylere yönelik yapılan çalışmaların gözden geçirilmesi. Ankara Üniversitesi Ĕ̈itim Bilimleri Fakültesi Özel Eğitim Dergisi. Advance online publication. https://doi.org/10.21565/ozelegitimdergisi.696065

\section{EXTENDED ABSTRACT}

Problem: The differences of twice exceptional individuals prevent them from being diagnosed correctly. This situation also prevents the provision of appropriate educational services. Sufficient evidence-based and theoretical knowledge must be together in order to provide appropriate special education services to these individuals (Rubenstein et al., 2013). However, it is seen that the number of experimental studies conducted with twice exceptional individuals with Autism Spectrum Disorder (ASD) is limited. For this reason, twice exceptional individuals may be overlooked or subject to ineffective programs (Huber, 2007).

Existing information should be considered as a whole in order to accurately identify and plan appropriate interventions. However, although there are many studies about ASD in the literature, very limited information can be reached about individuals with both gifted and ASD. In addition, it is seen that there are studies that review studies about twice exceptional individuals (Beckmann \& Minnaert, 2018; Y1lmaz-Yenioğlu \& Melekoğlu, 2020). However, it is seen that there is a limited number of studies reviewing studies on twice exceptional individuals with ASD (Foley-Nicpon et al., 2011). It is thought that there is a need to review existing information by combining studies conducted with twice exceptional individuals with ASD. In this way, it will be possible to make a judgment about the current situation in the literature and make suggestions for future research.

In this direction, the purpose of this research is to systematically review the studies conducted with twice exceptional individuals with ASD.

Method: This study is a systematic literature review. In this cotext, ERIC, ProQuest, ULABİM, and DergiPark were scanned in September 2020. The keywords "autism", "twice exceptional", "gifted", "talented", "otizm", "iki kere farkl1", "özel yetenek", "üstün yetenek", and "üstün zeka" were used. 473 studies reached in the first phase. In this context, title, abstract, method, and references sections were examined. As a result of the examination, 17 studies that meet the criteria were selected for this research.

The identified studies were examined under the themes of characteristics, diagnosis process, interventions, and families of twice exceptional individuals with autism.

Findings: It has been determined that twice exceptional individuals exhibit higher performance than their peers with typical development and ASD in terms of academic achievement (Chain et al., 2019), and they display a similar performance with their gifted peers (Assouline et al., 2009). The areas in which these individuals experience difficulties are shown as processing speed, executive functions, language, social skills, social adaptation, and psychosocial functions (Assouline et al., 2009; Doobay et al., 2014; Foley-Nicpon et al., 2010; Foley-Nicpon et al., 2012; Melogno et al., 2015). 
The necessity of adding ASD evaluation to the identification processes of giftedness is expressed (Assouline et al., 2009). However, the tools used in the assessment of ASD may give inconsistent results in distinguishing these individuals (Cederberg et al., 2018).

Approaches that focus on students' strengths and in keeping with their disabilities give effective results (Baum et al., 2014; Kuo et al., 2010; Wu et al., 2019). However, studies conducted with this purpose are limited.

The families of these individuals have difficulties in accessing appropriate educational services and effective methods for their child (Besnoy et al., 2015; Rubenstein et al., 2015).

Suggestions: The concept of masking should be considered in the context of weak socialcommunicative skills despite strong academic and cognitive skills, especially for twice exceptional individuals with ASD.

Multiple assessment approaches should be adopted in the diagnostic processes of twice exceptional individuals. Specialists working in the diagnostic processes should be recieved training about twice exceptionality.

There is a need to increase theoretical and evidence-based knowledge about twice exceptional students. In this way, the information needed by both families, educators, and other experts can be provided. 